Bangladesh J. Bot. 48(4): 919-924, 2019 (December)

\title{
IMPACT OF CHEMICAL AND ORGANIC FERTILIZER ON THE YIELD AND NUTRITIONAL COMPOSITION OF BAMBARA GROUNDNUT (VIGNA SUBTERRANEA L. VERDE.)
}

\author{
Mahmudul Hasan, Md Kamal Uddin ${ }^{1 *}$, Mahmud Tengku Muda Mohammed ${ }^{2}$, \\ Ali Tan Kee Zuan ${ }^{1}$ and Motmainna \\ Department of Land Management, Universiti Putra Malaysia, Malaysia \\ Keywords: Chemical fertilizer, Compost, Yield, Bambara groundnut, Seed quality
}

\begin{abstract}
A pot experiment was conducted to find out the effects of chemical and organic fertilizer on the yield and nutritional composition of bambara groundnut (Vigna subterranea). The size of the pot was $65.94 \mathrm{~cm}^{2}$. Different rates of compost, biofertilizer, gypsum was used along with the combination of different doses of nitrogen and phosphorus fertilizer. $\mathrm{N}$ and $\mathrm{P}$ fertilizers were found to play dominating role to increase yield and nutritional composition of the plant. Number of pod (41.75), 100-seed weight (34.25 g), protein (22.15\%), Ca (803.25 mg/ka) increased with the application of $\mathrm{N}$ and $\mathrm{P} 30$ and $60 \mathrm{~kg} / \mathrm{ha}$, respectively which was better than all other treatments. The application of $\mathrm{N}_{30}+\mathrm{P}_{60} \mathrm{~kg} / \mathrm{ha}$ increased yield and nutritional composition of bambara groundnut.
\end{abstract}

\section{Introduction}

Bambara groundnut (Vigna subterranea) is basically cultivated in the west and central Africa but now its cultivation has spread all over the world. It can be grown in all kinds of soil especially in marginal soil. Although urea is the most suitable source of $\mathrm{N}$, the plants do not use more than $50 \%$ (Hayat et al. 2012) and through volatilization, denitrification and leaching the remaining $\mathrm{N}$ is lost. Phosphorus furnishes superior root and soil contact which outcome the higher absorption of mineral nutrients. Application of nitrogen and phosphorus fertilizer increases the growth and yield of bambara groundnut (Hasan et al. 2018). Biofertilizer (B-Green biofertilizer) are cost-effective and also the renewable on the basis of plant to acquire essential nutrients. Biofertilizer supply nutrient like nitrogen and phosphorus and their actions in the soil or rhizosphere and formulate them into an obtainable form for plants. A legume lives in association with rhizobium bacteria and helps to improve the soil status (Okon 2016). In the composted organic wastes a little amount of $\mathrm{C}: \mathrm{N}$ ratios exits which are very useful for improving crop yields (Hayat et al. 2012). Soil bacteria are one of the important biotic components that influence decomposition and nutrient mineralization in the terrestrial ecosystem (Laldinthar and Dkhar 2015). Bambara groundnut is considered as balanced diet because of the high per cent of carbohydrate (65\%), protein (18\%) and fat $(6.5 \%)$ in the seed (Mazahib et al. 2013). The milk of bambara groundnut used as preventing milk. So far very little reports on the effects of chemical and organic fertilizer on bambara groundnut are available especially in Malaysia. Hence, the present study was carried out to evaluate the impact of chemical and organic fertilizer on yield and nutritional composition of bambara groundnut.

\section{Materials and Methods}

A pot experiments was conducted from February to June in 2017 at the Faculty of Agriculture in Ladang 15, Universiti Putra Malaysia. The size of the pot was $65.94 \mathrm{~cm}^{2}$. There were 40

*Author for correspondence: <mkuddin07@gmail.com>. ${ }^{1}$ Department of Land Management, Universiti Putra Malaysia, Malaysia. ${ }^{2}$ Department of Crop Science, Universiti Putra Malaysia, Malaysia. 
experimental units (pot) and in each pot one seed was sowed. Sandy clay loam soil was used to fill the pot and the amount was $10 \mathrm{~kg} / \mathrm{plot}$. N, P and $\mathrm{K}$ were mixed with the soil in the form of urea, triple super phosphate (TSP) and MOP. Ten different levels of chemical and organic fertilizers $\left(\mathrm{T}_{1}: \mathrm{N}_{30}+\mathrm{P}_{60} \mathrm{~kg} / \mathrm{ha}, \mathrm{T}_{2}: \mathrm{N}_{20}+\mathrm{P}_{60} \mathrm{~kg} / \mathrm{ha}, \mathrm{T}_{3}: \mathrm{N}_{25}+\mathrm{P}_{50}+\mathrm{K}_{75} \mathrm{~kg} / \mathrm{ha}, \mathrm{T}_{4}:\right.$ compost $2.5 \mathrm{t} / \mathrm{ha}, \mathrm{T}_{5}$ : compost $5.00 \mathrm{t} / \mathrm{ha}, \mathrm{T}_{6}$ : compost $7.5 \mathrm{t} / \mathrm{ha}, \mathrm{T}_{7}$ : compost $10 \mathrm{t} / \mathrm{ha}, \mathrm{T}_{8}$ : B-green biofertilizer $15 \mathrm{~kg} / \mathrm{ha}$, $\mathrm{T}_{9}$ : gypsum $400 \mathrm{~kg} / \mathrm{ha}$ and $\mathrm{T}_{10}$ : B-green biofertilizer $15 \mathrm{~kg} / \mathrm{ha}+$ gypsum $400 \mathrm{~kg} / \mathrm{ha}$ ) were applied. The experiment was performed in RCBD with four replications.

Yield data collected included the number of pods per plant, pod dry weight, (100) seed weights and shelling per cent (SP). To determine SP, bambara groundnut was put in a bag and air dried thoroughly to a moisture level of $13 \%$ before shelling. These were then weighed before shelling. After shelling, the shelled seeds were weighed and recorded. The SP was determined as the weight of dry seed divided by dry weight of pods.

The amount of protein was measured by Kjeldahl method (Kjeldahl 1883). An extraction of lipid was utilized by using Soxtec System (Soxtec System 2050 Foss Tecator) (Lin et al. 2006). To determine the moisture per cent in the seed, oven was used (Willits 1951). Fiber determination was carried out by utilizing Fibertec System (Fenton and Fenton 1979). The mineral composition of the seed was determined by dry ashing method (Cotteine 1980).

All data were subjected to ANOVA using SAS version 9.4 at the 5\% significance level and least significant difference was employed for mean separation (Gomez and Gomez 1984).

\section{Results and Discussion}

The effect of different rates of chemical and organic fertilizer had significant impact on yield parameters of bambara groundnut (Table 1). But the effects of different chemical and organic fertilizer level on SP and harvest index (HI) of bambara groundnut did not vary significantly. As soon as the vegetative stage finish, pod are started to form until harvest. Application of $\mathrm{N}$ and $\mathrm{P}$ increased the pod number at $\mathrm{T}_{1}$ and it was statistically dissimilar to all other applied fertilizer (Table 1). This indicates that number of pod increase with increasing $\mathrm{N}$ and $\mathrm{P}$ level. $\mathrm{T}_{1}\left(\mathrm{~N}_{30}+\mathrm{P}_{60}\right.$ $\mathrm{kg} / \mathrm{ha}$ ) treatment had the highest $(62.14 \%)$ increased on number of pod per plant when compost was applied at $2.5 \mathrm{t} / \mathrm{ha}$ (Table 1). There exists an increasing trend with increasing fertilizer and compost level. The growth and yield differences among the chemical and organic treatments have been related to $\mathrm{N}, \mathrm{P}$ and $\mathrm{K}$ availability to crops and release pattern by organic residues (Leconte et al. 2011). This result is similar to the finding of Khan et al. (2018).

In the application of $\mathrm{T}_{1}\left(\mathrm{~N}_{30}+\mathrm{P}_{60} \mathrm{~kg} / \mathrm{ha}\right)$ number of pods per plant, 100-seed weight and number of seeds per pod were significantly higher than all other treatments effect. The highest number of pods per plant (41.75) was observed at the treatment of $\mathrm{T}_{1}$ and lowest (25.75) was in $\mathrm{T}_{4}$ (compost $2.5 \mathrm{t} / \mathrm{ha}$ ). On the other hand, $\mathrm{T}_{1}$ treatment had the highest increased at $(42.19,43.98$ and $20.68 \%$ ) on pod fresh weight, pod dry weight, 100-seed weight, respectively when $\mathrm{N}$ and $\mathrm{P}$ was applied at $\mathrm{N}_{30}+\mathrm{P}_{60} \mathrm{~kg} / \mathrm{ha}$ (Table 1) in compared to $\mathrm{T}_{4}$ (compost $2.5 \mathrm{t} / \mathrm{ha}$ ). These results indicated that the plants which were fertilized with highest amount of $\mathrm{N}$ and $\mathrm{P}$ was registered the better result in yield parameter. Ntundu et al. (2006) also reported that there was significant difference among the bambara groundnut plant for yield related characteristics.

Treatment $\mathrm{T}_{1}\left(49.67 \mathrm{~g}\right.$ ) also produced the highest pod weight and $\mathrm{T}_{4}$ (compost $\left.2.5 \mathrm{t} / \mathrm{ha}\right)(34.95$ g) lowest. This result was quite dissimilar with the result of Ellah and Singh (2008) because of lower application of $\mathrm{P}(0,15,30 \mathrm{~kg} / \mathrm{ha})$.The difference observed between the treatments might be due to the fact that in the organic residues, nutrient availability depends on nutrient concentration and release with synchrony with crop needs. In the present study, the highest plant growth and 
yield reported at $\mathrm{N}_{30}+\mathrm{P}_{60} \mathrm{~kg} / \mathrm{ha}$ could be attributed to the nutrients being readily available from the source.

Table 1. Effect of chemical and organic fertilizer on NPPP, PFwt, PDwt, SW-100, SPP, SP and HI.

\begin{tabular}{clllllll}
\hline Treatment & NPPP & PFwt $(\mathrm{g})$ & PDwt & SW-100 & SPP & SP & HI \\
\hline $\mathrm{T}_{1}$ & $41.75 \mathrm{a}$ & $49.68 \mathrm{a}$ & $19.15 \mathrm{a}$ & $34.25 \mathrm{a}$ & $1.25 \mathrm{bc}$ & $74.53 \mathrm{a}$ & $48.53 \mathrm{ab}$ \\
$\mathrm{T}_{2}$ & $34.75 \mathrm{bcd}$ & $41.35 \mathrm{bc}$ & $16.35 \mathrm{ab}$ & $32.38 \mathrm{abc}$ & $1.00 \mathrm{c}$ & $69.60 \mathrm{abc}$ & $45.03 \mathrm{~b}$ \\
$\mathrm{~T}_{3}$ & $29.50 \mathrm{de}$ & $46.40 \mathrm{ab}$ & $18.58 \mathrm{a}$ & $33.20 \mathrm{ab}$ & $1.50 \mathrm{abc}$ & $72.50 \mathrm{ab}$ & $49.18 \mathrm{ab}$ \\
$\mathrm{T}_{4}$ & 25.75 & $34.95 \mathrm{~d}$ & $13.30 \mathrm{~b}$ & $28.38 \mathrm{e}$ & $1.00 \mathrm{c}$ & $65.93 \mathrm{bc}$ & $49.75 \mathrm{ab}$ \\
$\mathrm{T}_{5}$ & $28.50 \mathrm{de}$ & $35.93 \mathrm{~cd}$ & $16.23 \mathrm{ab}$ & $30.25 \mathrm{cde}$ & $1.00 \mathrm{c}$ & $73.83 \mathrm{ab}$ & $52.78 \mathrm{a}$ \\
$\mathrm{T}_{6}$ & $26.25 \mathrm{e}$ & $35.28 \mathrm{~d}$ & $14.58 \mathrm{~b}$ & $29.20 \mathrm{de}$ & $2.00 \mathrm{a}$ & $63.03 \mathrm{c}$ & $50.85 \mathrm{ab}$ \\
$\mathrm{T}_{7}$ & $33.75 \mathrm{bcd}$ & $39.68 \mathrm{~cd}$ & $16.05 \mathrm{ab}$ & $31.63 \mathrm{bcd}$ & $1.50 \mathrm{abc}$ & $73.63 \mathrm{ab}$ & $50.53 \mathrm{ab}$ \\
$\mathrm{T}_{8}$ & $31.50 \mathrm{cde}$ & $37.85 \mathrm{~cd}$ & $14.15 \mathrm{~b}$ & $29.45 \mathrm{de}$ & $1.25 \mathrm{bc}$ & $68.45 \mathrm{abc}$ & $50.65 \mathrm{ab}$ \\
$\mathrm{T}_{9}$ & $37.50 \mathrm{abc}$ & $41.07 \mathrm{bc}$ & $14.07 \mathrm{~b}$ & $29.93 \mathrm{cde}$ & $1.50 \mathrm{abc}$ & $68.45 \mathrm{abc}$ & $45.25 \mathrm{ab}$ \\
$\mathrm{T}_{10}$ & $38.00 \mathrm{ab}$ & $47.98 \mathrm{a}$ & $18.35 \mathrm{a}$ & $32.28 \mathrm{abc}$ & $1.75 \mathrm{ab}$ & $69.50 \mathrm{abc}$ & $50.98 \mathrm{ab}$ \\
\hline
\end{tabular}

$\mathrm{T}_{1}: \mathrm{N}_{30}+\mathrm{P}_{60} \mathrm{~kg} / \mathrm{ha}, \mathrm{T}_{2}: \mathrm{N}_{20}+\mathrm{P}_{60} \mathrm{~kg} / \mathrm{ha}, \mathrm{T}_{3}: \mathrm{N}_{25}+\mathrm{P}_{50}+\mathrm{K}_{75} \mathrm{~kg} / \mathrm{ha}, \mathrm{T}_{4}:$ compost $2.5 \mathrm{t} / \mathrm{ha}, \mathrm{T}_{5}$ : compost 5.00 t/ha, $\mathrm{T}_{6}$ : compost $7.5 \mathrm{t} / \mathrm{ha}, \mathrm{T}_{7}$ : compost $10 \mathrm{t} / \mathrm{ha}, \mathrm{T}_{8}$ : B-green biofertilizer $15 \mathrm{~kg} / \mathrm{ha}, \mathrm{T}_{9}$ : gypsum $400 \mathrm{~kg} / \mathrm{ha}$ and $\mathrm{T}_{10}$ : B-green biofertilizer $15 \mathrm{~kg} / \mathrm{ha}+$ gypsum $400 \mathrm{~kg} / \mathrm{ha}$. Means with the same letter have no significant difference.

Table 2. Effect of different rates of compost on proximate composition (\%) from the seed of bambara groundnut.

\begin{tabular}{ccccc}
\hline Treatments & Moisture & Ash & Protein & Fibre \\
\hline $\mathrm{T}_{1}$ & $3.05 \mathrm{a}$ & $3.53 \mathrm{a}$ & $22.15 \mathrm{a}$ & $6.45 \mathrm{a}$ \\
$\mathrm{T}_{2}$ & $3.03 \mathrm{a}$ & $3.35 \mathrm{a}$ & $20.55 \mathrm{~b}$ & $5.48 \mathrm{bc}$ \\
$\mathrm{T}_{3}$ & $3.13 \mathrm{a}$ & $3.68 \mathrm{a}$ & $20.43 \mathrm{bc}$ & $5.70 \mathrm{ab}$ \\
$\mathrm{T}_{4}$ & $3.13 \mathrm{a}$ & $3.18 \mathrm{a}$ & $19.48 \mathrm{cde}$ & $5.00 \mathrm{bc}$ \\
$\mathrm{T}_{5}$ & $3.08 \mathrm{a}$ & $3.43 \mathrm{a}$ & $19.50 \mathrm{cde}$ & $4.58 \mathrm{c}$ \\
$\mathrm{T}_{6}$ & $3.28 \mathrm{a}$ & $3.38 \mathrm{a}$ & $18.68 \mathrm{~b}$ & $4.85 \mathrm{bc}$ \\
$\mathrm{T}_{7}$ & $3.03 \mathrm{a}$ & $3.45 \mathrm{a}$ & $19.33 \mathrm{de}$ & $4.60 \mathrm{c}$ \\
$\mathrm{T}_{8}$ & $3.23 \mathrm{a}$ & $3.38 \mathrm{a}$ & $19.45 \mathrm{cde}$ & $4.98 \mathrm{bc}$ \\
$\mathrm{T}_{9}$ & $3.35 \mathrm{a}$ & $3.53 \mathrm{a}$ & $19.95 \mathrm{bcd}$ & $5.05 \mathrm{bc}$ \\
$\mathrm{T}_{10}$ & $3.18 \mathrm{a}$ & $3.38 \mathrm{a}$ & $19.68 \mathrm{bcde}$ & $5.20 \mathrm{bc}$
\end{tabular}

$\mathrm{T}_{1}: \mathrm{N}_{30}+\mathrm{P}_{60} \mathrm{~kg} / \mathrm{ha}, \mathrm{T}_{2}: \mathrm{N}_{20}+\mathrm{P}_{60} \mathrm{~kg} / \mathrm{ha}, \mathrm{T}_{3}: \mathrm{N}_{25}+\mathrm{P}_{50}+\mathrm{K}_{75} \mathrm{~kg} / \mathrm{ha}, \mathrm{T}_{4}:$ compost $2.5 \mathrm{t} / \mathrm{ha}, \mathrm{T}_{5}:$ compost 5.00 t/ha, $\mathrm{T}_{6}$ : compost $7.5 \mathrm{t} / \mathrm{ha}, \mathrm{T}_{7}$ : compost $10 \mathrm{t} / \mathrm{ha}, \mathrm{T}_{8}$ : B-green biofertilizer $15 \mathrm{~kg} / \mathrm{ha}, \mathrm{T}_{9}$ : gypsum $400 \mathrm{~kg} / \mathrm{ha}$ and $\mathrm{T}_{10}$ : B-green biofertilizer $15 \mathrm{~kg} / \mathrm{ha}+$ gypsum $400 \mathrm{~kg} / \mathrm{ha}$. Means with the same letter have no significant difference.

Proximate composition (Protein, fibre) contents in the seed of bambara groundnut were positively influenced by the application of different rates of chemical and organic fertilizer (Table 2). Moisture and ash contents of the seed were not showed any significant difference. The mean highest protein content $(22.15 \%)$ was recorded by the used of $\mathrm{T}_{1}$ and significantly different from 
other fertilizer and compost level. $\mathrm{T}_{1}$ gave $13.56 \%$ more advanced in protein content compare to $\mathrm{T}_{6}$. The lowest protein content $(18.68 \%)$ was registered in the application of $\mathrm{T}_{6}$. There was a decrease in protein content in the seed of bambara groundnut with decreasing $\mathrm{N}$ and $\mathrm{P}$ level.

Results also revealed that protein and fibre content increased with increase rate of $\mathrm{N}$ and $\mathrm{P}$ level. This increment could be due to the vital of $\mathrm{N}$ and $\mathrm{P}$ in enlargement of vegetative growth of plant parts. However, protein and fibre contents were higher than the value reported for raw groundnut seeds (Adeyeye 2011). This is because protein and fibre may be restricted the plants to grow in soils having low sulfur. These results are in agreement with findings of Soto et al. (2004). $\mathrm{N}$ and $\mathrm{P}$ contribute greatly to the synthesis of fibre and protein and the higher $\mathrm{N}$ and $\mathrm{P}$ available to the crop; the higher protein can be synthesized. High level of protein in bambara groundnut would make it useful in supplementing the nutrients derived from tubers and cereals in places where other legumes are not easily available.

Table 3. Effect of different rates of compost on mineral composition $(\mathrm{mg} / \mathrm{kg})$ from the seed of bambara groundnut.

\begin{tabular}{|c|c|c|c|c|c|c|c|}
\hline \multirow[t]{2}{*}{ Treatments } & $\mathrm{Ca}$ & $\mathrm{K}$ & $\mathrm{Mg}$ & $\mathrm{Mn}$ & $\mathrm{Zn}$ & $\mathrm{Cu}$ & $\mathrm{Fe}$ \\
\hline & \multicolumn{2}{|c|}{ Macronutrients } & & \multicolumn{4}{|c|}{ Micronutrients } \\
\hline $\mathrm{T}_{1}$ & $803.25 \mathrm{a}$ & $529.0 \mathrm{a}$ & $717.0 \mathrm{a}$ & $25.1 \mathrm{a}$ & $66.95 a$ & $4.6 \mathrm{a}$ & $58.8 \mathrm{ab}$ \\
\hline $\mathrm{T}_{2}$ & $719.75 b$ & $482.5 b c$ & $639.0 \mathrm{~b}$ & $24.3 \mathrm{ab}$ & $56.7 \mathrm{bc}$ & $3 \mathrm{bcd}$ & $59.7 \mathrm{a}$ \\
\hline $\mathrm{T}_{3}$ & $714.75 b$ & $484.5 \mathrm{~b}$ & $651.0 \mathrm{~b}$ & $22.2 \mathrm{a}-\mathrm{d}$ & $55.1 \mathrm{bc}$ & $3.8 \mathrm{bc}$ & $57.4 \mathrm{a}-\mathrm{c}$ \\
\hline $\mathrm{T}_{4}$ & $602.5 a-c$ & $400.0 \mathrm{e}$ & $606.8 b c$ & $19.4 d$ & $45.0 \mathrm{~d}$ & $1.9 \mathrm{e}$ & $52.9 \mathrm{a}-\mathrm{c}$ \\
\hline $\mathrm{T}_{5}$ & $624.8 \mathrm{de}$ & $401.5 \mathrm{e}$ & $602.0 \mathrm{bc}$ & $20.9 \mathrm{bcd}$ & $50.5 \mathrm{~cd}$ & $2.2 \mathrm{de}$ & $50.3 \mathrm{c}$ \\
\hline $\mathrm{T}_{6}$ & $637.3 \mathrm{de}$ & 419de & $589.3 \mathrm{bc}$ & $20.4 \mathrm{~cd}$ & $51.6 \mathrm{bcd}$ & $2.2 \mathrm{de}$ & $51.9 \mathrm{bc}$ \\
\hline $\mathrm{T}_{7}$ & $644.3 \mathrm{cde}$ & $415.3 \mathrm{de}$ & $564.0 \mathrm{c}$ & $22.6 a-d$ & $53.0 \mathrm{bc}$ & $2.6 \mathrm{cde}$ & $58.9 \mathrm{ab}$ \\
\hline $\mathrm{T}_{8}$ & $680.3 \mathrm{bcd}$ & $442.3 \mathrm{~cd}$ & $621.3 b c$ & $24.4 \mathrm{ab}$ & $54.0 \mathrm{bc}$ & $2.8 \mathrm{bcde}$ & $58.2 \mathrm{ab}$ \\
\hline $\mathrm{T}_{9}$ & $685.8 \mathrm{bcd}$ & 440.0de & $604.8 \mathrm{bc}$ & $23.4 \mathrm{ab}$ & $58.1 \mathrm{~b}$ & $3.1 \mathrm{bcd}$ & $59.7 \mathrm{a}$ \\
\hline $\mathrm{T}_{10}$ & $706.5 \mathrm{bc}$ & $448.8 \mathrm{bcd}$ & $628.5 b c$ & 23abcd & $57.0 \mathrm{bc}$ & $3.5 \mathrm{~b}$ & $57.6 \mathrm{abc}$ \\
\hline
\end{tabular}

$\mathrm{T}_{1}: \mathrm{N}_{30}+\mathrm{P}_{60} \mathrm{~kg} / \mathrm{ha}, \mathrm{T}_{2}: \mathrm{N}_{20}+\mathrm{P}_{60} \mathrm{~kg} / \mathrm{ha}, \mathrm{T}_{3}: \mathrm{N}_{25}+\mathrm{P}_{50}+\mathrm{K}_{75} \mathrm{~kg} / \mathrm{ha}, \mathrm{T}_{4}:$ compost $2.5 \mathrm{t} / \mathrm{ha}, \mathrm{T}_{5}$ : compost $5.00 \mathrm{t} / \mathrm{ha}$, $\mathrm{T}_{6}$ : compost $7.5 \mathrm{t} / \mathrm{ha}, \mathrm{T}_{7}$ : compost $10 \mathrm{t} / \mathrm{ha}, \mathrm{T}_{8}$ : B-green biofertilizer $15 \mathrm{~kg} / \mathrm{ha}, \mathrm{T}_{9}$ : gypsum $400 \mathrm{~kg} / \mathrm{ha}$ and $\mathrm{T}_{10}$ : B-green biofertilizer $15 \mathrm{~kg} / \mathrm{ha}+$ gypsum $400 \mathrm{~kg} / \mathrm{ha}$. Means with the same letter have no significant difference.

The results showed that application of chemical and organic fertilizer at different rates varied significantly on macronutrient $\mathrm{Ca}, \mathrm{K}, \mathrm{Mg}$ and $\mathrm{Cu}$ and $\mathrm{Zn}$ varied significantly (Table 3 ). There was no significant difference on $\mathrm{Mn}$ and $\mathrm{Fe}$ content in seed of bambara groundnut. The highest $\mathrm{Ca}$ was gained in the treatment of $T_{1}$ and $T_{2}$ as compared to $T_{4}$. The applied level of fertilizer and compost affected the Ca content in the seed of bambara groundnut. Application of $\mathrm{T}_{1}$ exposed an increment of $33.3 \%$ than $\mathrm{T}_{4}$. But slightly higher Ca content was reported by (Adam et al. 2015) that 958.0 to $990.0 \mathrm{mg} / \mathrm{kg}$.

The Mg content in the seed ranges from 606.8 to $717.0 \mathrm{mg} / \mathrm{ka}$. Mg content $18.16 \%$ increase compared to $\mathrm{T}_{4}$. Similar result was reported by (Benvindo 2018). The $\mathrm{Zn}$ content in the seed measured in the treatment of $T_{1}$ was significantly higher than the effect of all other treatment. The Zn content was increased $48.8 \%$ at $T_{1}$ compared to $T_{4}$. The treatment $T_{2}$ and $T_{3}$ were statically 
similar but significantly better than the $\mathrm{T}_{4}$. This result is similar to the findings of Ijarotimi and Esho (2009).

Bambara groundnut is an edible legume which serves as one of the main sources of income for small holder farmers. The yield related character and nutritional composition of the plant increased with $\mathrm{N}_{30} \mathrm{~kg} / \mathrm{ha}$ and $\mathrm{P}_{60} \mathrm{~kg} / \mathrm{ha}$ fertilizer application. The application of $\mathrm{N}_{30}$ and $\mathrm{P}_{60} \mathrm{~kg} / \mathrm{ha}$ could be recommended for obtaining maximum yield and nutritional composition of bambara groundnut.

\section{Acknowledgements}

The authors are grateful to project (GP-IPM/2016/9494700) for funding this research and also sincerely acknowledge the authorities of the University Putra Malaysia for providing all land and laboratory facilities.

\section{References}

Adam M, Abdualrahman Y, Ali AO and Elkhalifa EA 2015. Chemical, minerals, fatty acid and amino acid compositions of sudanese traditional khemiss-Tweria supplemented with peanut and bambara groundnuts. Amer. J. Food Technol. 3: 100-108.

Adeyeye EI 2011. Effects of processing on the nutritional and anti-nutritional factors of (Arachis hypogaea) groundnut seed flour. Int. J. Chem. Sci. 1: 131-142.

Benvindo V, Benjamin D and Jayne M 2018. Influence of manure, phosphate fertilizer and lime on soil available NPK and uptake of NP by soybean in Embu county, Kenya. Discovery 54(265): 13-22.

Cotteine A 1980. Soil and plant testing as a basis of fertilizer recommendation. pp. 100. Rome, Italy.

Ellah MM and Singh A 2008. Bambara groundnut (V. subterranea) yield as influenced by phosphorus and cultivars in the semi-arid Savanna of Nigeria. J. Plant. Sci. 3: 176-181.

Fenton TW and Fenton M 1979. An improved procedure for the determination of chromic oxide in feed and feces. Can. J. Anim. Sci. 3: 631-634.

Gomez KA and Gomez AA 1984. Statistical Procedures for Agricultural Research. 2nd Edt. A Wiley Inter Science Publication, Jhon Wiley and Sons New York. pp. 704.

Hasan M, Uddin MK, Mohamed MTM and Zuan KTA. (2018). Nitrogen and phosphorus management for Bambara groundnut (Vigna subterranea) production - A review. Legume. Res. 41(4): 483-489.

Hayat R, Iftikhar-ul-hassan M, Akram S and Sheirdil RA 2012. Evaluation of compost application for improving legumes yield and $\mathrm{N}_{2}$ fixation. Afr. J. Biotechnol. 41: 9758-9764.

Ijarotimi OS and EshoTR 2009. Comparison of nutritional composition and anti-nutrient status of fermented, germinated and roasted bambara groundnut seeds (Vigna subterranea). Brit. Food. J. 4: 376-386.

Khan MR, Rahman MH, Hasan M, Sarker RR, Ali MM. (2018). Nutrient management for rice-fallow-rice cropping pattern grown under costal saline area of Satkhira, Bangladesh. Int. J. Biosci. 12(2): 310-316.

Kjeldahl J 1883. A new method for the determination of nitrogen in organic matter. J. Anal. Chem. 1: 366382.

Laldinthar R and Dkhar MS 2015. Relationship between soil bacterial population and various physicochemical properties at two broad leaved forest stands of Meghalaya differing in altitudes. Transcriptomics 3: 125.

Leconte MC, Mazzarino MJ, Satti P and Crego MP 2011. Nitrogen and phosphorus release from poultry manure composts: the role of carbonaceous bulking agents and compost particle sizes. Biol. Fertil. Soils. 47(8): 897-906.

Lin H, Li ZC, Yong-qing Z and Wen-hui 2006. Effect of dietary traditional chinese medicines on apparent digestibility coefficients of nutrients for white shrimp. Aquaculture. 253: 495-501.

Mazahib AM, Nuha MO, Salawa IS and Babiker EE 2013. Some nutritional attributes of bambara groundnut as influenced by domestic processing. Int. Food. Res. J. 3: 1165-1171. 
Ntundu W, Shillah S, Marandu W and Christiansen JL 2006. Morphological diversity of bambara groundnut (Vigna subterranea L. Verdc.) landraces in Tanzania. Gent. Resour. Crop. Ev. 53: 367-378.

Okon JE 2016. Effects of groundnut spacing on yield and weed control in the rainforest agro-ecological zone of Nigeria. Res. J. Agric. and Food Sci. 12: 374-377.

Soto PO, Jahn EB and Arredondo SS 2004. Improvement of protein percentage in corn silage with an increase in and partitioning of nitrogen fertilization. Agric. Téc. 64 (2): 156-162.

Willits CO 1951. Methods for determination of moisture-oven drying. Anal. Chem. 8: 1058-1062.

(Manuscript received on 10 August, 2018; revised on 26 October, 2018) 